\title{
Tax-Saving Components on Tax Disclosures
}

\author{
Ricy Apriliyan ${ }^{1}$, Estralita Trisnawati ${ }^{1 *}$, Herlina Budiono $^{1}$ \\ ${ }^{1}$ Faculty of Economics and Business, Universitas Tarumanagara, Jakarta, Indonesia \\ *Corresponding author. Email: estralitat@fe.untar.ac.id
}

\begin{abstract} Keywords: Tax disclosures, tax planning, tax saving

\section{INTRODUCTION}

Taxes are mandatory contributions originating from tax subjects and given to the state. For companies, taxes are a burden that can reduce the company profits. As for the state, taxes are used to finance the administration, carried out by the government for people welfare. But unfortunately, taxpayers are not fully aware of the importance of taxes to the country. This is evident from the low tax-ratio in Indonesia. The tax-ratio for the last eight years can be seen in Table 1 below.
\end{abstract}

The purpose of this study was to examine the influence of tax planning, as measured by the use of tax saving, consisting of permanent differences, temporary differences, foreign tax-rates differentials, and tax losses on tax disclosures. The sample in this study was 21 consumer good manufacturing companies listed in the Indonesia Stock Exchange (IDX) for 7 years (from 2012 to 2018). The results of this study are: 1) Permanent differences has an influence on tax disclosures, 2) Temporary differences has an influence on tax disclosures, 3) Foreign tax-rate differentials has no influence on tax disclosures, and 4) Tax losses have an influence on tax disclosures.

Table 1 Indonesia Tax-Ratio (2012-2019)

\begin{tabular}{|l|l|l|l|l|l|l|l|l|}
\hline Years & 2012 & 2013 & 2014 & 2015 & 2016 & 2017 & 2018 & 2019 \\
\hline $\begin{array}{l}\text { Tax } \\
\text { Ratio }\end{array}$ & $14.6 \%$ & $14.3 \%$ & $13.7 \%$ & $11.6 \%$ & $10.8 \%$ & $10.7 \%$ & $11.6 \%$ & $12.1 \%$ \\
\hline
\end{tabular}

Source: kemenkeu.go.id

According to the Minister of Finance, Ms. Sri Mulyani, the low tax-ratio in Indonesia is due to the practice of tax resistance among taxpayers [1], whereas tax resistance can be passive or active.

Tax disclosures can be associated with tax avoidance. The disclosure of tax in the financial statements is a concrete form of tax planning [8].

The result from [2] shows that in Australia large companies experience several reactions from consumers. Large companies take some steps to avoid tax disclosures to public. It was also found that investors responded negatively to the disclosure of true tax information. Currently, political and public pressure is acting to end dangerous tax practices carried out by companies such as illegal tax planning. The purpose of this pressure is to increase the amount of information that can be accessed by public through tax disclosures as well as to increase the corporate compliance and accountability [3]. The disclosure of tax information to public is one of the instruments of tax policy. [4] recommended that tax authorities acquire the information in tax disclosures by making a trade-off for managers, namely whether to hide information from tax authorities or to provide valuable information to stakeholders. The result of [2] shows that private companies in Australia experience several consumer reactions, while some companies take action to avoid disclosing tax information. They found that investors responded negatively. In 2013, [5] and [6] stated that there was an increase in the attention of tax disclosures to companies. Sweden, Norway, and Finland currently have policies requiring public disclosure of taxable corporate profits. Meanwhile in the United States, Wisconsin already has the disclosure regulations that are used for tax-policy purposes [7] [8].

Research on tax disclosures is still rare, so this research is a replication of previous research conducted by [6] with the independent variables consisting of permanent differences, temporary differences, foreign tax-rates differentials, and tax losses, and the dependent variable is tax disclosures. This research was conducted to test the consistency with previous research using the data in Indonesia.

The result of the research conducted by [6] on tax-saving components concluded that permanent differences have a significant and negative effect on tax disclosures. This is evidenced in the negative impact of permanent differences on tax aggressiveness [9] and [10]. The result of the research conducted by [6] resulted in the conclusion that temporary differences have a significant and negative effect on tax disclosures. This is in line with [11] and [12], because deferred-tax obligations are not documented. However, these findings are inconsistent with [13], which linked the increase in temporary differences with an increase in aggressive tax-planning. The result of the research conducted by [6] shows that foreign tax-rates differentials have no significant effect on tax disclosures. This is because this component has a low impact on the evaluation of tax savings for interested parties. However, this result contradicts [14] whereas foreign tax-rates differentials indicate effective tax-planning activities. [9] concluded that shareholders might judge that every loss that occurs in each company is a measure of tax planning through tax saving. However, this depends on the disclosure of tax information that is presented in the company's financial statements. The result of the research conducted by [6] provides a 
conclusion that tax losses have a significant and positive effect on tax disclosures.

The purpose of this study was to obtain empirical evidence regarding tax disclosures. This research is expected to provide new knowledge in the existing tax research besides tax avoidance and tax aggressiveness.

\section{LITERATURE REVIEW AND HYPOTHESIS DEVELOPMENT}

The signalling theory is the most relevant theory and fuels the argument about tax disclosures [8]. The signalling theory states that companies issue the "signals" about what they believe and who they are [15]. What disclosed by companies includes the information about taxes, depending on their motivation. These motivations vary and have different effects on the disclosure level among the firms and countries. This is based on several reasons, for example, tax laws [16]. A further possibility of using the signalling theory is that managers may wish to provide some asymmetric information regarding the firm performance through the dissemination of financial reports. For example, disclosures can be the "signals" when they reflect the information about the unobservable attributes of a firm's decision [17].

\section{Permanent differences on tax disclosures}

Permanent differences are the components of tax saving. According to [10] [9] and [6], the users of financial statements evaluate the companies and find that those companies take aggressive actions in tax reporting with high permanent differences and temporary differences. This provides a signal in tax disclosures, whereas permanent differences can indicate the companies' ability to carry out strategic tax-planning actions or activities. Based on the explanation above, the hypothesis can be formulated as follow:

$\mathrm{H}_{1}$ : Permanent differences have an effect on tax disclosures.

\section{Temporary differences on tax disclosures}

Temporary differences are the components of tax saving. According to [18], temporary differences are one of the concerns of many companies, because temporary differences as the components of tax saving can result in an increase in cash flow [19]. Temporary differences also represent the information in the disclosure of taxes in the financial statements. The information in this tax disclosures provides a signal to the stakeholders and shareholders of financial statements. [11] supports the relationship between temporary differences and tax disclosures. Based on the above discussion regarding temporary differences from tax saving to tax disclosures, the following hypothesis was formulated as follow:

$\mathrm{H}_{2}$ : Temporary differences have an effect on tax disclosures.

\section{Foreign tax-rates differentials on tax disclosures}

Foreign tax-rates differentials are a component of tax saving. [18] stated that companies must disclose the tax information separately in the financial statements. [20] claimed that multinational companies that have disclosed their material operations with no less than one country, experience a relatively low universal tax-burden [21]. Tax saving that comes from foreign tax-rates differentials is obtained from the multinational companies having operations abroad in various tax-jurisdictions [9].

Foreign tax-rates differentials are associated with tax disclosures, because they show the effective tax-planning actions to forward the accurate predictive information [14] and [20]. Based on this explanation, a hypothesis was formulated, namely:

$\mathrm{H}_{3}$ : Foreign tax-rates differentials affect tax disclosures.

\section{Tax losses on tax disclosures}

[21] shows that the fourth component of tax saving is tax losses. Companies can estimate these tax losses by focusing on their operating losses as exhibited in the income statement. According to [8], the parties involved in the company will probably appreciate each tax loss as part of the tax planning. This depends on the items presented in the company's financial statements. The result of the research conducted by [6] concluded that tax losses have a significant and positive effect on tax disclosures. Companies that experience tax losses will not be a subject to income tax. Tax losses include the information in the disclosure of taxes in the financial statements. Information on tax losses in tax disclosures is a signal what the company provides to its stakeholders. Hence, it could be hypothesized as follow:

$\mathrm{H}_{4}$ : Tax losses have an effect on tax disclosures.

\section{RESEARCH METHOD}

The population in this research is manufacturing companies in the consumer goods sector listed in the Indonesia Stock Exchange (IDX) during the period of 2012-2018.

The sampling technique used in this study was purposive sampling, with 21 consumer goods manufacturing companies listed in the IDX within the research period. This study used the consumer goods manufacturing companies, because the products of these companies are very important to be used in daily life.

The following is the operationalization of variables used in this study.

Table 2 The Operationalization of Variables

\begin{tabular}{|c|l|c|}
\hline$\#$ & Variable & \multicolumn{1}{|c|}{ Indicator } \\
\hline 1 & $\begin{array}{l}\text { Permanent } \\
\text { Difference } \\
\text { (PD) }\end{array}$ & PD $1=\frac{1}{\text { joint venture }}$ \\
profit before tax
\end{tabular}




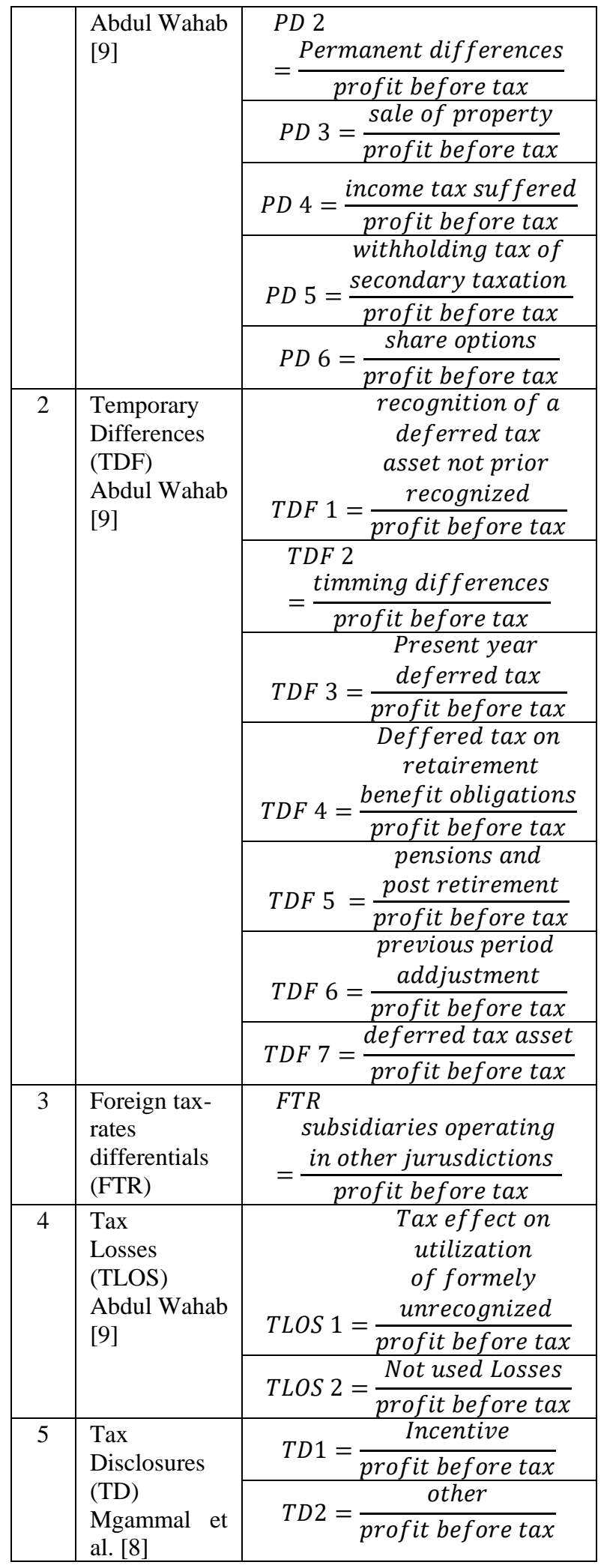

This study used the IBM SPSS version 23 software for descriptive data analysis and SmartPLS 3 for conducting the outer-model, inner-model, and hypotheses tests.

\section{RESEARCH RESULTS}

In this study, the descriptive statistical test using SPSS 23 software in the period of 2012-2018, shows that the N-value is the amount of data used as many as 147 samples. Before testing the hypotheses, the outer-model was tested using SmartPLS 3.0, consisting of convergent validity, discriminant validity, and reliability. Convergent validity test is done by using the outer-loading and AVE values, whereas all variables have passed this test. The result of the outer-loading test, namely the permanent differences variable used 1 indicator, namely PD5 of 0.514 ; temporary differences variable used 2 indicators, namely TDF2 and TDF7 of 0.848 and 0.724 ; tax losses variable used 1 indicator, namely TDLOS1 of 0.526 ; and tax disclosures variable used 1 indicator, namely TD2 of 0.939 . After that, the test of discriminant validity was conducted, whereas the indicators in this study have met the requirements, and it has also passed the reliability test using Cronbach's Alpha and the composite reliability of 0.830 .

In the inner-model test, it was carried out by using two tests, namely the $\mathrm{R}^{2}$-Adjusted in this study shows a value of 0.173 , which can be categorized as a weak research model due to the variables of permanent differences, temporary differences, foreign tax-rates differentials, and tax losses, can only explain the effect of $17.3 \%$ tax disclosures and the remaining $82.7 \%$ was explained by other variables not in the scope of this research model. The $\mathrm{Q}^{2}$ test result shows a value of 0.120 , whereas the influence of the variables of permanent differences, temporary differences, foreign taxrates differentials, and tax losses has good predictive relevance to tax disclosures.

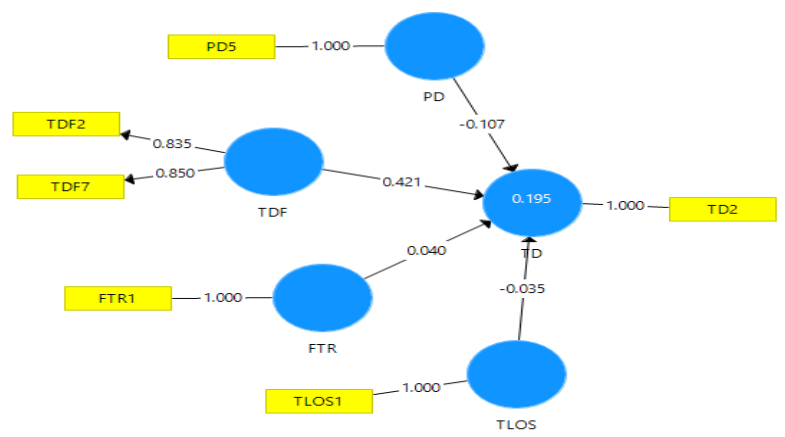

Figure 1 The Result of Research Model Source: The Results of Data Processing Using SmartPLS 3.0

The hypothesis tests were done by using bootstrapping tests. As the result of bootstrapping test, the t-statistics must show the value greater than 1.64 , and the p-value must be less than 0.05 . The results of bootstrapping tests can be observed in Table 3 as follows. 
Table 3 The Bootstrapping-Test Results

\begin{tabular}{|l|c|c|c|c|c|}
\hline & $\begin{array}{c}\text { Path } \\
\text { Coefficient }\end{array}$ & $\begin{array}{c}\text { Sample } \\
\text { Mean } \\
(\mathrm{M}))\end{array}$ & $\begin{array}{c}\text { Standard } \\
\text { Deviation } \\
(\text { STDEV })\end{array}$ & $\begin{array}{c}\text { t-Statistics } \\
(\text { (O/STDEV) })\end{array}$ & $\begin{array}{c}\mathrm{p}- \\
\text { Values }\end{array}$ \\
\hline $\mathrm{PD} \rightarrow$ TD & -0.107 & -0.095 & 0.054 & 1.993 & 0.047 \\
\hline $\begin{array}{l}\text { TDF } \\
\text { TD }\end{array}$ & 0.421 & 0.402 & 0.154 & 2.733 & 0.007 \\
\hline $\begin{array}{l}\text { FTR } \rightarrow \\
\text { TD }\end{array}$ & 0.040 & 0.037 & 0.066 & 0,612 & 0.541 \\
\hline $\begin{array}{l}\text { TLOS } \\
\text { TD }\end{array}$ & -0.035 & -0.038 & 0.016 & 2.213 & 0.027 \\
\hline
\end{tabular}

Source: The Results of Data Processing Using SmartPLS 3.0

Based on Table 3 above, the t-statistics value of the permanent differences variable is 1.993 (greater than 1.64) and the p-value is 0.047 (less than 0.05 ) so that $\mathrm{H}_{1}$ was accepted. The t-statistics value of the temporary differences variable is 2.733 (greater than 1.64) and the p-value is 0.007 (less than 0.05) so that $\mathrm{H}_{2}$ was accepted. The t-statistics value of the foreign tax-rates differentials variable is 0.612 (greater than 1.64) and the p-value is 0.541 (less than 0.05) so that $\mathrm{H}_{3}$ was rejected. This means that the foreign tax-rates differentials have no effect on tax disclosures. And the last, the t-statistics value of the tax losses variable is 2.213 (greater than 1.64) and the p-value is 0.027 (less than 0.05), so $\mathrm{H}_{4}$ was accepted.

\section{DISCUSSIONS}

The result of this study concluded that permanent differences have a significant effect on tax disclosures. This is consistent with the previous studies by [10] [9] and [6]. There is a significant effect of permanent differences on tax disclosures, because permanent differences are an element that is often used to show a company's ability to carry out the strategic tax-planning activities.

This study concluded that temporary differences have a significant effect on tax disclosures. This is consistent with the research by [11] and [6], which support the relationship between tax disclosures and temporary differences. The effect of temporary differences on tax disclosures is very significant, because temporary differences are the most frequently used element of tax saving. This is also in accordance with [18], whereas temporary differences are one of the concerns for parties who have interests in the company. Temporary differences are an element of tax saving that can result in an increase in cash flow [19].

The result of this study concluded that foreign tax-rates differentials do not have a significant effect on tax disclosures. This is in line with [6], which stated that foreign tax-rates differentials have no effect on tax disclosures. This shows that the foreign tax-rates differentials component is still not widely used for tax-saving activities which can be seen from the small sample of companies in the study, with a mean of 0.1886 , which uses the opportunity for differences in rates between countries in tax saving for interested parties [6]. This result of this research differs from [14] regarding foreign tax-rate differentials with tax disclosures, because the differences in foreign tax-rates show that tax planning is effective for forward-looking information as an accurate estimate.

This study concluded that the tax losses variable significantly affects tax disclosures. So, this result supports the research from [21]. However, this result is not in line with [6], because based on the findings, the conclusion is that tax losses have a significant and positive effect on tax disclosures.

\section{CONCLUSIONS}

Based on the result of data analysis in this study, it shows that permanent differences, temporary differences, and tax losses partially have significant effect on tax disclosures. Only foreign tax-rates differentials have no effect on tax disclosures. This is due to the fact that only a few companies sampled in this study have not used the tax-rate component in other countries. Overall, based on the results of this study, it can be known that the sample companies still use the old, more familiar ways, to carry out the tax-planning activities such as permanent and temporary differences and tax losses. New methods such as foreign tax-rates differentials, financial derivatives, and others should also be used

This study has some limitations, which are: (1) This study only uses consumer goods manufacturing companies listed in the IDX during the period 2012-2018. (2) This study only uses 4 independent variables, namely, permanent differences, temporary differences, differences in foreign tax-rates, and tax losses. Based on the above limitations, the suggestion for further researchers is to add independent variables that can explain tax disclosures, such as tax planning, financial derivatives, splitting companies, and so on.

\section{REFERENCES}

[1] Sukmana, Y., Rasio Pajak Masih Rendah, Sri Mulyani Heran, https://money.kompas.com/read/ 2017/07/12/191629826/rasio-pajak-masihrendah-srimulyani-heran. access on June 26, 2020.

[2] Hoopes, J.L., Robinson, L., and Slemrod, J., Public tax-return disclosure, Journal of Accounting and Economics, 66 (1), pp 142-162, 2018.

[3] Graham, J. R., Hanlon, M., Shevlin, T., and Shroff, N., Incentives for tax planning and avoidance: evidence from the field, The Accounting Review, 89 (3), pp. 9911023, 2014.

[4] Hardock, I., Inger, K. K., Moore, R. D., \& Schneider, J. (2018). Cross-Cultural Evidence on Tax Disclosures in CSR Reports - A Textual Analysis Approach. SSRN Electronic Journal · January 2018 
[5] Hasegawa, M., Hoopes, J. L., Ishida, R. and Slemrod, J. (2013). The effect of public disclosure on reported taxable income: evidence from individuals and corporations in Japan, National Tax Journal, Vol. 66 No. 3: 571-607.

[6] Mgammal, M. H., The effect of components of tax saving on tax disclosure: A panel data approach in Malaysian listed companies, Pacific Accounting Review, 31 (4) (2019) 574-601. DOI: doi.org/10.1108/PAR-10-2018-0080

[7] Mazerov, M., State corporate tax disclosure, Washington, DC: Center on Budget and Policy Priorities, 2007.

[8] Mgammal, M. H., Bardai, B., and KuIsmail, K.N.I., Corporate governance and tax disclosure phenomenon in the Malaysian listed companies, Corporate Governance: The International Journal of Business in Society, 18 (5) (2018), pp. 779-808. doi:10.1108/CG1108-2017-0202,18(5).

[9] AbdulWahab, N.S., Tax planning and corporate governance: effects on shareholders valuation, Thesis for the degree of Doctor of Philosophy, University of Southampton, 2010.

[10] Frank, M.M., Lynch, L.J. and Rego, S.O., Tax reporting aggressiveness and its relation to aggressive financial reporting. The Accounting Review, 84 (2) (2009), pp 467-496.

[11] Evers, M. T., Finke, K., Matenaer, S., Meier, I. and Zinn, B. (2014). Evidence on book-tax differences and disclosure quality based on the notes to the financial statements, ZEW-Centre for European Economic Research Discussion Paper.

[12] Mgammal, M. H. (2015). The effect of tax planning and corporate governance on tax disclosure in Malaysia, Thesis for the degree of Doctor of Philosophy, University Utara Malaysia, Sinto, Kedah.

[13] Mills, L., Erickson, M. and Maydew, E. (1998). Investments in tax planning, Journal of the American Taxation Association, Vol. 20 No. 1: 1-20.

[14] Schmidt, A. P. (2006). The persistence, forecasting and valuation implications of the tax change component of earnings, The Accounting Review, Vol. 81 No. 3: 589-616.

[15] Spence, M. (1973). Job market signalling, The Quarterly Journal of Economics, Vol. 87 No. 3: 355374.
[16] Bhattacharya, S. and Ritter, J. R. (1983). Innovation and communication: signalling with partial disclosure, The Review of Economic Studies, Vol. 50, No. 2: 331-346.

[17] Morris, N. W. (1989). The Association between Selected Corporate Attributes and Management Incentives for Voluntary Accounting Disclosure, University Microfilms, Ann Arbor, MI.

[18] Bauman, M. P. and Shaw, K. W. (2008). The usefulness of disclosures of untaxed foreign earnings in firm valuation, Journal of the American Taxation Association, Vol. 30, No. 2: 53-77.

[19] Lev, B. and Nissim, D. (2010). Taxable income, future earnings, and equity values, The Accounting Review, Vol. 79 No. 4: 1039-1074.

[20] Dyreng, S. D., Hanlon, M. and Maydew, E. L. (2010). "The effects of executives on corporate tax avoidance", The Accounting Review, Vol.85 No.4: 1163-1189.

[21] Atwood, T. and Reynolds, J. K. (2008). The pricing of realized tax benefits from nol carry forwards: effect of income statement presentation, Journal of the American Taxation Association, Vol. 30, No.1: 1-27. 